\title{
Instream $C$ sources for primary consumers in two temperate, oligotrophic rivers: possible evidence of bryophytes as a food source
}

\author{
Sherisse M. McWilliam-Hughes ${ }^{1}$, Timothy D. Jardine ${ }^{2}$, \\ AND Richard A. Cunjak ${ }^{3}$ \\ Department of Biology, University of New Brunswick, Fredericton, New Brunswick, E3B 5A3, Canada
}

\begin{abstract}
Aquatic food webs use C derived from 2 sources: autochthonous (derived from inside the water body) and allochthonous (derived from outside the water body). Various autochthonous sources are available to consumers (e.g., algae, mosses, macrophytes), and stable isotope analysis can be used to differentiate among $C$ sources and to determine which sources sustain aquatic communities. The goal of our study was to determine which $C$ sources contribute to the autochthonous pathways in 2 oligotrophic rivers, the Upper Salmon and Big Salmon, in New Brunswick (Canada). Samples were taken from headwaters to river mouth (above head of tide) at 17 study sites distributed across subbasins and stream orders. Vegetation samples included macrophytes, filamentous algae, biofilm, and aquatic bryophytes. Macroinvertebrate taxa in the scraper (grazer) functional feeding group were collected to represent primary consumers that feed primarily on autochthonous food sources. Macrophyte and cyanobacteria $\delta^{13} \mathrm{C}$ values were correlated with scraper $\delta^{13} \mathrm{C}$ values $\left(r=0.55\right.$ and 0.47 , respectively), but $\delta^{13} \mathrm{C}$ of most scrapers was more depleted than $\delta^{13} \mathrm{C}$ of these food sources $(>40 \%$ and $>90 \%$, respectively). Trophic fractionation is primarily an enrichment process, so these results indicated that macrophytes and cyanobacteria were not important food sources for primary consumers. Filamentous algae and biofilm $\delta^{13} \mathrm{C}$ values were poorly correlated with scraper $\delta^{13} \mathrm{C}$ values $(r=0.36$ and 0.40 , respectively), and $>60 \%$ of the values were too depleted for these sources to be important food sources for scrapers. Ninety-eight percent of scraper $\delta^{13} \mathrm{C}$ values were enriched relative to bryophyte $\delta^{13} \mathrm{C}$ values, and bryophyte $\delta^{13} \mathrm{C}$ values were correlated with scraper $\delta^{13} \mathrm{C}$ values $(r=0.53)$, particularly when samples from slow-flowing habitats were removed from the analysis $(r=0.76)$. Spatial distributions of 2 important bryophyte taxa differed. Fontinalis sp. was abundant in headwater streams, and Drepanocladus sp. was abundant in low-order streams. Scrapers in low-order streams seemed to depend more on Fontinalis sp. than scrapers in highorder streams depended on Drepanocladus sp. Our results suggest that in low-productivity, nutrient-limited rivers, reduced availability of more preferred food sources (e.g., epilithic algae) might cause primary consumers to switch to marginal food sources, such as bryophytes. Further research is required to confirm this hypothesis and to eliminate confounding factors.
\end{abstract}

Key words: autochthonous, food webs, stable isotopes, carbon, grazer, macroinvertebrate, bryophyte, aquatic moss, New Brunswick.

Development of robust theories of ecosystem structure and function in running waters depends on understanding stream food sources and energy flow (Odum 1971). These theories, in turn, are the basis of successful strategies for stream management (Cummins 1974). Productivity of aquatic food webs is

\footnotetext{
${ }^{1}$ E-mail address: smcw.hughes@unb.ca

2 Present address: Australian Rivers Institute, Griffith University, Nathan, Brisbane, Queensland, 4111, Australia. E-mail: t.jardine@griffith.edu.au

${ }^{3}$ E-mail address: cunjak@unb.ca
}

driven by their primary producers. Many different primary producers occur in aquatic food webs, but energy (C) sources in rivers typically are grouped as allochthonous or autochthonous (Hynes 1970, Vannote et al. 1980, Thorp et al. 1998). Allochthonous C sources originate outside stream boundaries and are transported into the system. These sources (often termed leaf litter) include leaves, twigs, flowers, nuts, limbs, and roots of terrestrial vegetation (Hynes 1970). Autochthonous $\mathrm{C}$ sources are indigenous to the stream (Wetzel 1975). These sources include submergent and emergent macrophytes, filamentous and suspended algae, epilithic and epiphytic algae, diatoms, autotro- 
phic and heterotrophic bacteria, and fungi. Not all autochthonous sources derive their resources from the aquatic environment; e.g., emergent macrophytes can convert atmospheric $\mathrm{CO}_{2}$ into plant tissue during photosynthesis (Madsen and Sand-Jensen 1991).

The relative importance of allochthonous and autochthonous $\mathrm{C}$ sources to aquatic consumers can be difficult to determine (Chapman 1966). Traditionally, consumer diets were studied with methods, such as gut content analysis (Petelle et al. 1979, Rounick and Winterbourne 1986), that provided the researcher a point-in-time reference of ingested material. Within the last $30 \mathrm{y}$, a more integrative approach, stable isotope analysis (SIA), has become increasingly popular (Fry 2006). SIA reflects only materials incorporated into tissues, so it provides a better indication of long-term nutrient assimilation than does gut content analysis (Rounick and Winterbourn 1986). Inferences about a consumer's diet are made by comparing its isotopic ratios $\left(\delta^{13} \mathrm{C}\right)$ with those of other species in its food web (Fry and Sherr 1984, Peterson and Fry 1987). This comparison is possible because trophic transfer causes predictable changes, or fractionations, in isotopic signatures of consumers relative to their diet (DeNiro and Epstein 1978, 1981).

$\delta^{13} \mathrm{C}$ ratios for primary producers vary because of source $C$ availability and differing methods of photosynthetic processing (Rounick and Winterbourn 1986). Typically, values for terrestrial $C_{3}$ plants fall within a narrow range around -28\% (Rau 1980, Rounick et al. 1982, France 1995a, Finlay 2001), whereas values for aquatic vegetation can vary from -50 to $-10 \%$ (Rounick and Winterbourn 1986, France 1995a). Although $\delta^{13} \mathrm{C}$ of primary producers can vary significantly from that of their $\mathrm{C}$ source, $\delta^{13} \mathrm{C}$ increases $<1 \%$ with each consumer in the food chain (Post 2002). Therefore, an organism retains the $\sim \delta^{13} \mathrm{C}$ value of its primary $\mathrm{C}$ source (DeNiro and Epstein 1978, Doucett et al. 1996). This fact, in conjunction with distinct differences in $\delta^{13} \mathrm{C}$ values of potential food sources, makes $\delta^{13} \mathrm{C}$ values useful for tracing $\mathrm{C}$ flow through an ecosystem (Fry and Sherr 1984).

Mixing models can be used to quantify the relative contribution of various food sources to consumers. However, they require isotopically distinct food sources at the local (site) scale (Phillips 2001). An alternative to the use of mixing models within sites is to compare isotope ratios of consumers and food sources across sites with a correlation or regression approach (Bunn et al. 2003). In our study, SIA was used to determine which of many aquatic primary producers contributed most to the autochthonous foods in food webs in the Upper Salmon and Big Salmon River systems, New Brunswick (NB). $\delta^{13} \mathrm{C}$

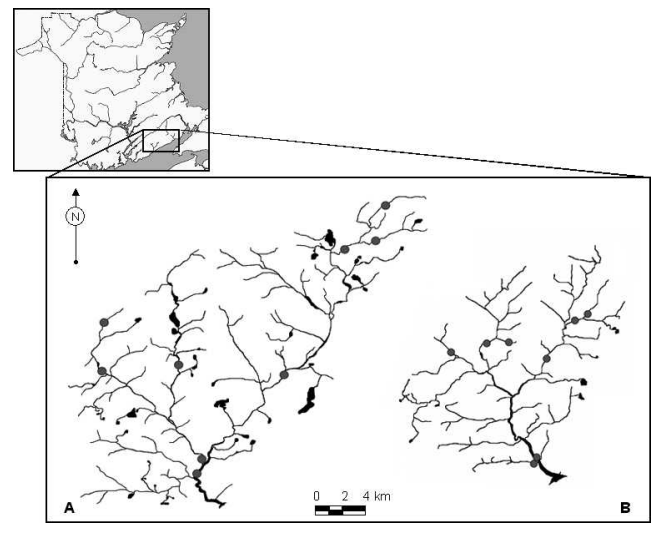

FIG. 1. Study sites on the Big Salmon (A) and Upper Salmon (B) rivers, New Brunswick, that were sampled in 2004 .

values of aquatic vegetation types were compared with $\delta^{13} \mathrm{C}$ values of primary consumers in the scraper (grazer) functional feeding group (FFG). Scrapers primarily consume autochthonous food sources. Allochthonous $\mathrm{C}$ sources can be important in food webs of temperate river systems, particularly in headwaters (Vannote et al. 1980), but were not included because our focus was the role of aquatic primary producers in the autochthonous pathway (i.e., grazing invertebrates). Epilithic algae are thought to be the most important autochthonous food source in running waters (Merritt and Cummins 1984, Allan 1995, Finlay 2001), and we predicted that biofilm would be the primary autochthonous food in local food webs. Sampling was done over a large spatial scale to determine if relationships between primary producers and consumers varied with stream order.

\section{Methods}

\section{Study locations}

The 2 rivers studied were the Big Salmon River (BSR; Fig. 1A) and the Upper Salmon River (USR; Fig. 1B). Study sites were selected along the lengths of the rivers from headwaters to river mouth to reflect the stream orders present in the 2 systems. The USR runs through Fundy National Park and empties into the Bay of Fundy near the village of Alma, NB, and drains $183 \mathrm{~km}^{2}$. The lower $49 \%\left(89 \mathrm{~km}^{2}\right)$ of the basin lies within park boundaries and is classified as a $4^{\text {th }}$ order stream in the North American Datum (NAD83; scale $=1: 50,000$; NGS 1983). Its annual hydrograph shows a snowmelt-driven high-water peak between mid-March and mid-May, and a smaller peak caused by autumn rains from October to December. The minimum and maximum recorded discharges be- 
tween 1967 and 1979 were $0.221 \mathrm{~m}^{3} / \mathrm{s}$ and $154 \mathrm{~m}^{3} / \mathrm{s}$, respectively. During the same period, mean annual discharge was $7.05 \mathrm{~m}^{3} / \mathrm{s}$ (Environment Canada 2007).

The BSR is $\sim 20 \mathrm{~km}$ west of Fundy National Park and drains $332 \mathrm{~km}^{2}$. The BSR is a $5^{\text {th }}$-order stream at its mouth (NAD83; scale $=1: 50,000$ ). Its annual hydrograph is similar to that of the USR. Mean annual discharge between 1970 and 1979 was $11.78 \mathrm{~m}^{3} / \mathrm{s}$. Minimum and maximum discharges were $0.62 \mathrm{~m}^{3} / \mathrm{s}$ and $140 \mathrm{~m}^{3} / \mathrm{s}$, respectively (Environment Canada 2007).

Most land in the 2 basins is forested with only a few small residential developments $\left(<2\right.$ people $/ \mathrm{km}^{2}$; Cunjak and Newbury 2005). Both catchments are in the Fundy Coast section of the Acadian Forest Region (Rowe 1972). Forest vegetation is mixed hardwood and softwood, and the characteristic tree species are red spruce (Picea rubens), balsam fir (Abies balsamea), sugar maple (Acer saccharum), and yellow birch (Betula alleghaniensis) (Woodley 1985).

Conductivity, a relative measure of enrichment and primary productivity (Biggs 1996), is low in the USR and BSR (range: 22.5-62.7 $\mu \mathrm{S} / \mathrm{cm}$ ), and $\mathrm{N}: \mathrm{P}$ ratios range from $20: 1$ to $60: 1$. Total $\mathrm{N}$ typically is $<0.4 \mathrm{mg} /$ $\mathrm{L}$, a value that suggests $\mathrm{P}$ limitation in these systems. $\mathrm{pH}$ ranges from 6.8 to 7.6 (SMM-H, unpublished data). Based on water chemistry and nutrient levels, these 2 systems can be described as low-productivity, $\mathrm{P}$-limited, neutral-pH rivers.

\section{Collections}

Samples were collected in July and November 2004 to represent times with high quantities of either autochthonous (summer) or allochthonous (autumn) C sources available. At each study site, duplicate collections were made in both fast- and slow-flow areas (typically, distinct riffle and pool habitats) to ensure collection of all possible food sources. Autochthonous sources, collected from the stream bottom, consisted of aquatic macrophytes, aquatic bryophytes (mosses and liverworts), filamentous algae, and biofilm (scraped from 4-6 randomly selected rocks to remove the matrix of algae, diatoms, bacteria, and fungi). Samples of different species of aquatic vegetation were collected from each study site and rinsed to remove any attached organisms and fine debris. Vegetation samples were not acidified with $10 \% \mathrm{HCl}$ because no carbonates were detected (Bunn et al. 1995), and low alkalinity and hardness values were recorded throughout the river systems (SMM-H, unpublished data). The amount of material collected for each autochthonous source was biased by the natural occurrence of sources in various habitats. For example, macrophytes occurred predominantly in slow-moving water; therefore, $>80 \%$ of these specimens were taken from pools, whereas biofilm was collected only from riffles because sediment might have contaminated samples from pools.

Aquatic macroinvertebrates were collected with a kick net (D-net; mesh size $=250 \mu \mathrm{m})$. Four samples were collected from each site, starting at the most downstream habitat to ensure that subsequent sampling locations were not disturbed. Samples were sorted to separate invertebrates from their food sources. Invertebrates were stored at cool temperatures for $24 \mathrm{~h}$ to allow gut contents to clear (DeNiro and Epstein 1978). Mollusk shells were removed to avoid contamination from nondietary carbonates (Bunn et al. 1995). Invertebrates were frozen prior to identification and SIA preparation.

\section{Analysis}

Macrophytes, bryophytes (mosses and liverworts), and algae were identified to genus (Prescott 1980, Sears 1998). All vegetation was diligently hand-picked to remove any invertebrates, detritus, and algae growing on, or entwined within, the various samples to ensure that a pure sample was analyzed. SIA of epiphytic algae removed from macrophyte and bryophyte samples was not possible because of insufficient amounts of algae.

Two groups of bryophytes, mosses and liverworts, were collected and analyzed for stable isotopes. The liverwort species (Chiloscyphus sp.) was isotopically distinct from both moss species (Fontinalis sp. and Drepanocladus sp.). Chiloscyphus sp. had an average $\delta^{13} \mathrm{C}$ of $-33 \%$, and $>80 \%$ of the $\delta^{13} \mathrm{C}$ values were between $-28 \%$ and $-35 \%$. No grazers had $\delta^{13} \mathrm{C}$ values within this range, a result that suggested Chiloscyphus sp. was not important in the food web. Therefore, this species was not included in subsequent analysis or interpretation.

Attempts were made to separate detritus from algae in the biofilm matrix with density fractionation in colloidal silica (Hamilton et al. 2005). Preliminary results were inconclusive, and additional analysis was required to refine the method and assess the efficacy of the separations. Additional experimentation was not possible because of budget and time constraints, so biofilm samples were sorted by hand under a dissecting microscope to remove detritus.

Invertebrates were identified to family with keys in Merritt and Cummins (1984) and were prepared for SIA separately. Whenever possible, individual invertebrates were analyzed. When body size was too small for analysis, several individuals were pooled for 
SIA. FFG classification (Merritt and Cummins 1984) was used when comparing invertebrate consumers to potential food sources. Scrapers (grazers) feed primarily on primary producers and were used to identify important autochthonous sources. Invertebrate taxa classified as obligate scrapers in our study were Blephariceridae (Diptera), Gastropoda (Mollusca), Glossosomatidae (Trichoptera), and Psephenidae (Coleoptera). Heptageniidae (Ephemeroptera) were classified as facultative scrapers (Merritt and Cummins 1984). Preliminary SIA of heptageniid mayflies yielded $\delta^{13} \mathrm{C}$ values comparable with those of scrapers, so heptageniids were used with obligate scrapers to assess important autochthonous food sources.

All organic tissue samples were dried at $60^{\circ} \mathrm{C}$ for $48 \mathrm{~h}$, ground into a fine homogenate with a mortar and pestle, and submitted for C and N SIA at the Stable Isotopes in Nature Laboratory, University of New Brunswick, Fredericton, NB. All samples were combusted and analyzed in a Finnigan Mat Delta Plus continuous-flow, isotope-ratio mass spectrometer (ISOMASS Scientific Inc., Calgary, Alberta) connected to a Thermoquest NC2500 elemental analyzer (ISOMASS Scientific Inc.).

Stable isotope ratios are expressed as $\delta$ values and are measured as parts per thousand (\%) differences relative to international standards:

$$
\delta X=\left[\left(R_{\text {sample }} / R_{\text {standard }}\right)-1\right] \times 1000
$$

where $X$ is ${ }^{13} \mathrm{C}$, and $R$ is the corresponding ratio ${ }^{13} \mathrm{C} /{ }^{12} \mathrm{C}$. The standard used for ${ }^{13} \mathrm{C}$ was PeeDee Belemnite carbonate (Craig 1957), which is arbitrarily set at $0 \%$. A greater $\delta$ value indicates enrichment of the heavier isotope component, whereas a smaller $\delta$ value indicates depletion of the heavier isotope.

Analytical error was calculated per Jardine and Cunjak (2005). The commercially available organic analytical standard (Acetanilide; Elemental Microanalysis Ltd., Devon, UK) had a mean $\left( \pm 1\right.$ SD) $\delta^{13} \mathrm{C}$ of $-33.62 \pm 0.25 \%$, whereas the internal standard, bovine liver standard, had a $\delta^{13} \mathrm{C}$ value of $-18.70 \pm$ $0.19 \%$. Within an analytical run, sample repeats never had 1 SD $>0.77 \%$, and $70 \%$ of sample repeats had 1 SD $<0.20 \%$. Invertebrate $\delta^{13} \mathrm{C}$ was lipid-corrected using the lipid normalization model presented in Logan et al. (2008) that uses C:N as a proxy for lipid content.

Three measures were used to help identify important primary producers: 1 ) the $1: 1$ line relating $\delta^{13} \mathrm{C}$ values of primary producers vs consumers, 2 ) the coefficient of determination $\left(r^{2}\right)$, and 3) the correlation coefficient (r) (Bunn et al. 2003). ${ }^{13} \mathrm{C}$ increases, on average, by $0.4 \%$ with each trophic transfer (DeNiro and Epstein 1978, Vander Zanden and Rasmussen 2001, McCutchan et al. 2003, Post 2002). Therefore, primary producers that are directly consumed should have data points that fall slightly above the 1:1 line in a consumer vs producer plot. We used $r^{2}$ and $r$ as measures of the strength and direction of associations between primary producers and consumers. Mean $\delta^{13} \mathrm{C}$ of primary producers were plotted against mean values of various primary consumers from respective habitats, sites, and seasons (SigmaPlot 10.0; Systat Software Inc., San Jose, California). Regression and correlation analyses were done for each vegetation type (NCSS 2004; NCSS, Kaysville, Utah). Variation in primary consumer $\delta^{13} \mathrm{C}$ values should track the spatial and temporal variation in the vegetation $\delta^{13} \mathrm{C}$ values if the vegetation is an important $C$ source (across all sites and times; Bunn et al. 2003).

\section{Results}

Five primary producer taxa were identified as potential autochthonous food sources for consumers in the study rivers: biofilm, macrophytes, cyanobacteria, filamentous algae (red and green), and aquatic bryophytes. $\delta^{13} \mathrm{C}$ of biofilm was poorly correlated with $\delta^{13} \mathrm{C}$ of scrapers $\left(r \approx 0.40, r^{2} \approx 0.16\right)$, and $>60 \%$ of the data points fell below the 1:1 line (i.e., most scrapers were more depleted in ${ }^{13} \mathrm{C}$ than were the biofilm samples; Fig. $2 \mathrm{~A}) . \delta^{13} \mathrm{C}$ of macrophytes was correlated with $\delta^{13} \mathrm{C}$ of scrapers $\left(r \approx 0.55, r^{2} \approx 0.30\right)$, and $>40 \%$ of the data points fell below the 1:1 line (Fig. 2B). $\delta^{13} \mathrm{C}$ of cyanobacteria was correlated with $\delta^{13} \mathrm{C}$ of scrapers $\left(r \approx 0.47, r^{2} \approx 0.22\right)$, and $>90 \%$ of the data points fell below the 1:1 line (Fig. $2 \mathrm{C}$ ). $\delta^{13} \mathrm{C}$ of filamentous algae was poorly correlated with $\delta^{13} \mathrm{C}$ of scrapers $\left(r \approx 0.36, r^{2} \approx 0.13\right)$, and $>60 \%$ of the data points fell below the 1:1 line (Fig. 2D). $\delta^{13} \mathrm{C}$ of mosses was correlated with $\delta^{13} \mathrm{C}$ of scrapers $\left(r \approx 0.53, r^{2}\right.$ $\approx 0.28$ ), and $98 \%$ of the data points fell on or above the 1:1 line (Fig. 3A). Thus, most scrapers were slightly enriched in ${ }^{13} \mathrm{C}$ compared with this potential food source.

Bryophytes in these rivers generally occur in riffles (i.e., fast-flow areas) rather than in pools. The pool samples were collected from transitional habitats (i.e., runs, tails of pools). When pool samples were removed from the analysis, the strength of the correlation between $\delta^{13} \mathrm{C}$ of mosses and $\delta^{13} \mathrm{C}$ of scrapers increased $\left(r \approx 0.76, r^{2} \approx 0.57\right.$; Fig. 3B). When pool samples were removed from the analyses for the other vegetation types, the strength of the correlations decreased or increased slightly (biofilm: not collected from pools; cyanobacteria: $r=0.15, r^{2}=0.02$; algae: $r$ $\left.=0.39, r^{2}=0.15\right)$, with the exception of macrophytes 


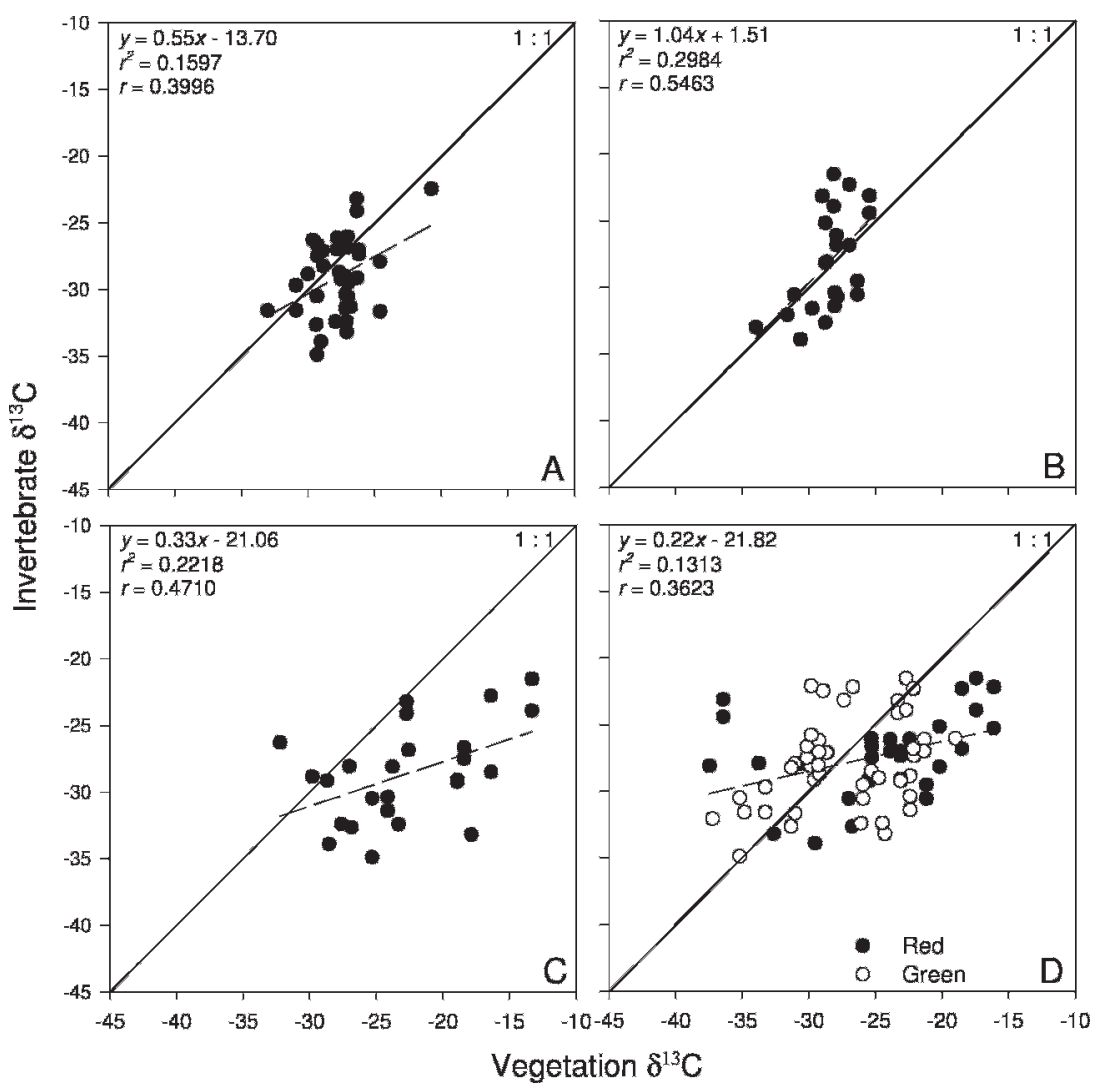

Fig. 2. Season-, site-, and habitat-specific values of invertebrate $\delta^{13} \mathrm{C}$ signatures plotted as a function of biofilm (A), macrophyte (B), cyanobacteria (C), and filamentous algae (D) $\delta^{13} \mathrm{C}$ signatures. Dashed lines and equations indicate regressions of the data points, and the solid line is the 1:1 line.

$\left(r=0.86, r^{2}=0.74\right)$. However, the sample size for macrophytes was very small $(n=7)$, and all data points fell below the 1:1 line.

The relationship between invertebrate and moss $\delta^{13} \mathrm{C}$ signatures did not differ between obligate scrapers and heptageniids (no apparent separation of invertebrate groups in Fig. 4A). This result indicates that the ranges of $\delta^{13} \mathrm{C}$ values of these invertebrate groups are similar throughout the 2 rivers. However, spatial distributions of bryophyte taxa varied. Both moss species, Fontinalis sp. and Drepanocladus sp., occurred in all stream orders, but Fontinalis sp. was more abundant in low- than in highorder streams and Drepanocladus sp. was more abundant in high- than in low-order streams. $\delta^{13} \mathrm{C}$ values of the 2 moss species differed, reflecting their spatial distributions (Fontinalis sp.: $\delta^{13} \mathrm{C}=-38$ to $-33 \%$; Drepanocladus sp.: $\delta^{13} \mathrm{C}=-30$ to $-25 \%$; Fig. 4B). The correlation and 1:1 line analyses (Fig. 4B) indicated that invertebrate $\delta^{13} \mathrm{C}$ in low-order streams was better correlated with $\delta^{13} \mathrm{C}$ of Fontinalis sp. $(r \approx$ 0.73) than invertebrate $\delta^{13} \mathrm{C}$ in high-order streams was correlated with $\delta^{13} \mathrm{C}$ of Drepanocladus sp. $(r \approx 0.63)$.

\section{Discussion}

\section{Biofilm}

We found little evidence to support our prediction that biofilm was the most important primary producer in the autochthonous pathway in these rivers. $\delta^{13} \mathrm{C}$ results indicate that most scrapers were more depleted in ${ }^{13} \mathrm{C}$ than were biofilm samples, a result suggesting that scrapers were not feeding primarily on biofilm. Moreover, very little biofilm grows on the stream beds of these rivers because of low productivity and nutrient limitation, especially in headwaters where closed canopies also reduce insolation. Grazing is an unlikely explanation for the scarcity of biofilm. Invertebrate abundance was not measured, but grazers constituted a very small proportion of individuals collected during our study (SMM-H, personal observation).

Biofilm assemblages consist of attached algae and detritus and includes microfloral and microfaunal elements (Wetzel 1975). Diatoms are the critical nutritional component of the biofilm matrix in streams (Allan 1995) and are consumed primarily by scrapers (Merritt and Cummins 1984, Finlay 2001). However, 


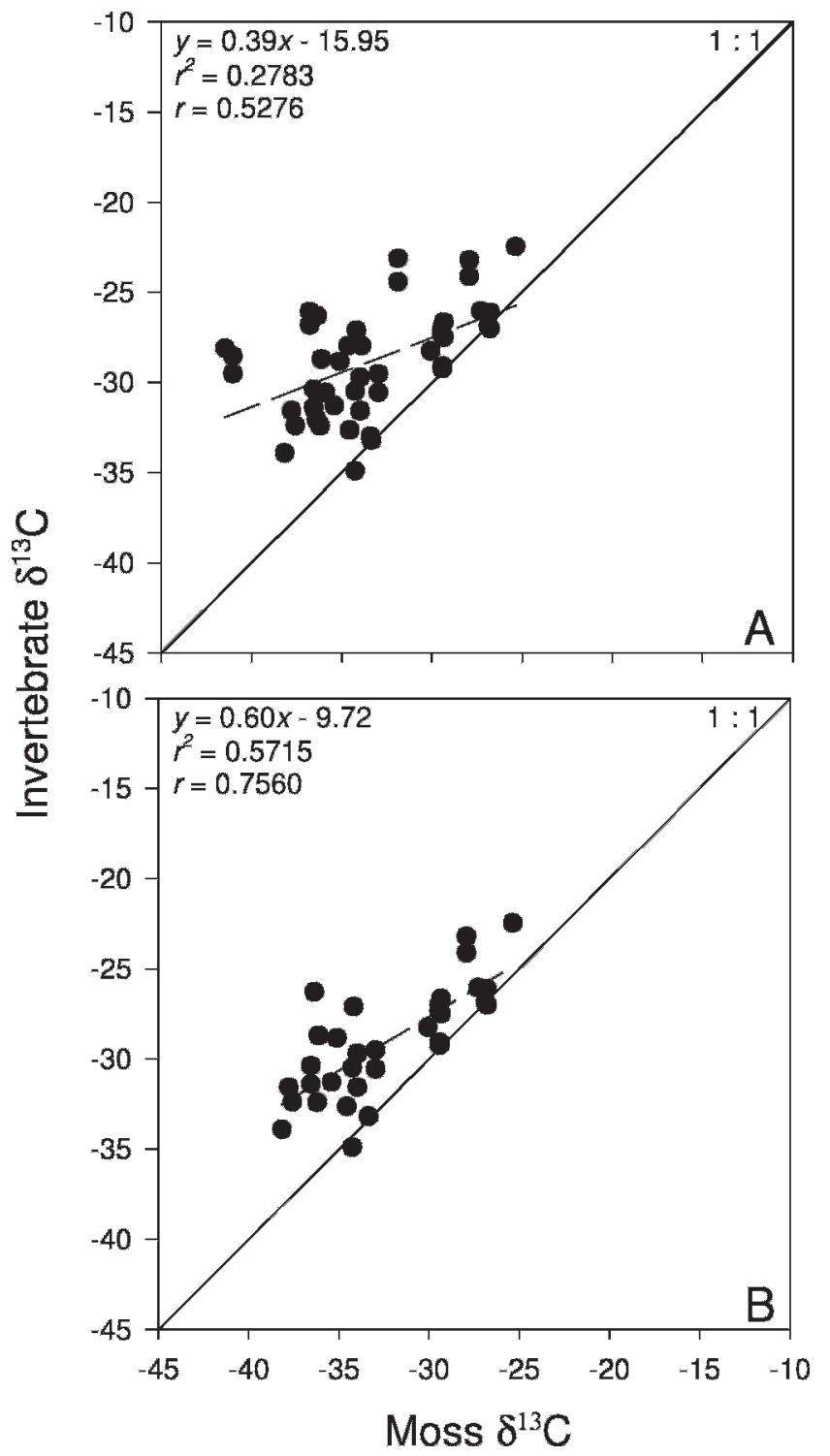

FIG. 3. Season-, site-, and habitat-specific values of invertebrate $\delta^{13} \mathrm{C}$ signatures plotted as a function of moss $\delta^{13} \mathrm{C}$ signatures in all samples (A) and excluding pool samples (B). Dashed lines and equations indicate regressions of the data points, and the solid line is the 1:1 line.

they often constitute the smallest fraction of biofilm on stream rocks (Madsen 1972, Cummins 1975). Particularly in headwater streams, detritus and other organic matter (e.g., bacteria, fungi) constitute most of the matrix, and isolation of a pure sample of epilithic microalgae is extremely difficult (Finlay 2001). Diatoms, bacteria, and fungi can have different $\delta^{13} \mathrm{C}$ values, and the signatures of components, such as detritus and heterotrophic bacteria, can mask the true $\delta^{13} \mathrm{C}$ signature of microalgae in the biofilm matrix. Selective consumption or selective assimilation of $\geq 1$ biofilm component could cause consumer $\delta^{13} \mathrm{C}$ values

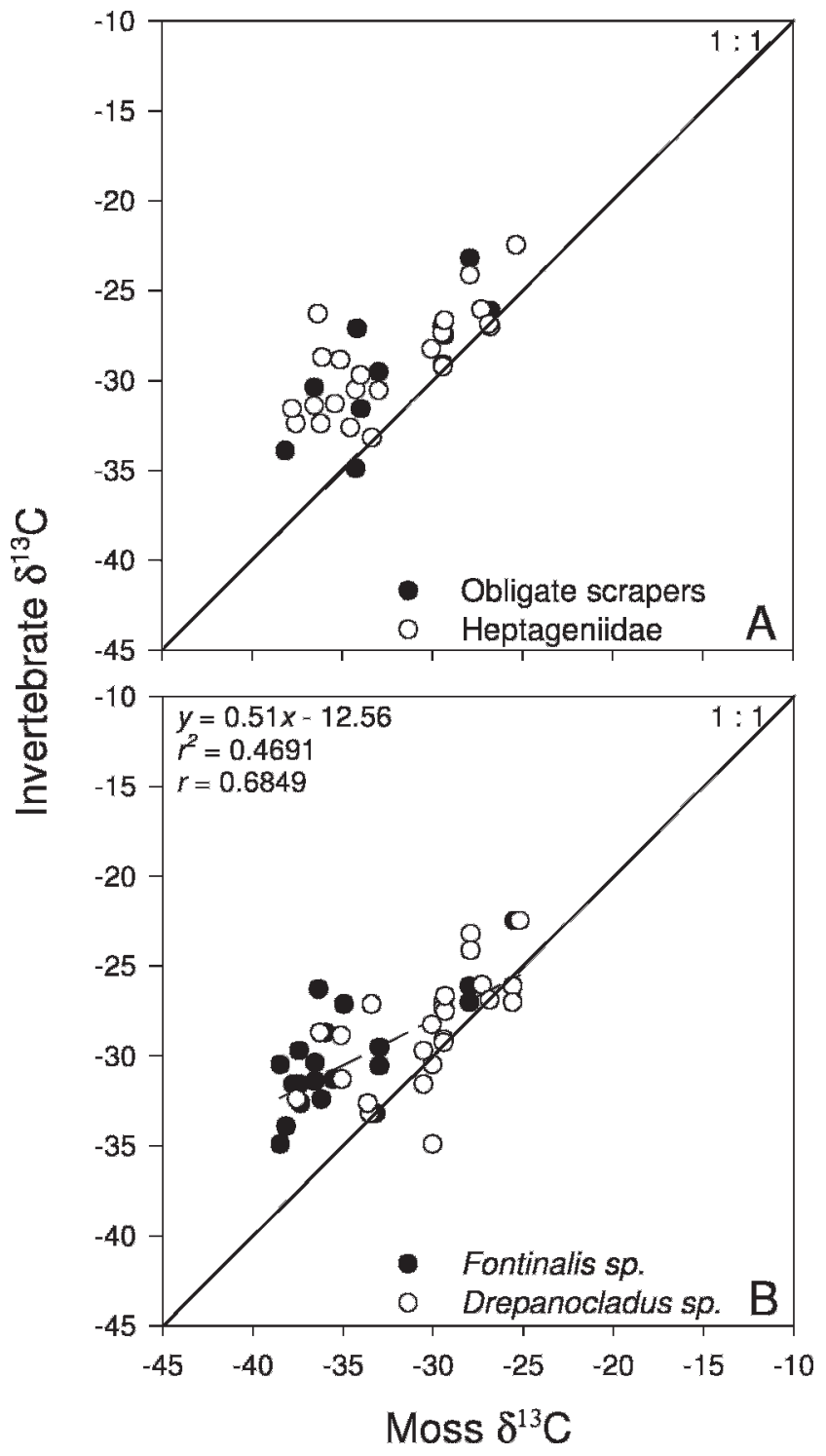

FIG. 4. Season-, site-, and habitat-specific values of invertebrate $\delta^{13} \mathrm{C}$ signatures plotted as a function of moss $\delta^{13} \mathrm{C}$ signatures in all samples such that obligate scrapers and Heptageniidae signatures (A) or Fontinalis sp. and Drepanocladius sp. signatures (B) are distinguished. Dashed lines and equations indicate regressions of the data points, and the solid line is the $1: 1$ line.

to differ from the $\delta^{13} \mathrm{C}$ value of the entire biofilm assemblage (Rounick et al. 1982). Therefore, despite its scarcity, biofilm cannot be eliminated completely as a possible $\mathrm{C}$ source, and it might be consumed in conjunction with another $\mathrm{C}$ source in these rivers.

\section{Macrophytes}

More than $40 \%$ of scrapers had $\delta^{13} \mathrm{C}$ values more depleted than macrophyte $\delta^{13} \mathrm{C}$ values. Macrophyte 
abundance and diversity were low at most study sites ( 8 sites had 0 species, 6 sites had $\leq 3$ species, 3 sites had 4-6 species). These results indicate that macrophytes were not an important direct source of $C$ for scrapers in these rivers. Vascular macrophytes serve an important indirect role in aquatic food webs, but their use as a food source has long been an area of debate (Shelford 1918, Frohne 1956, Lodge 1991, Newman 1991, France 1995b). Hynes (1970) stated that it is rare to find the leaves of higher plants (i.e., macrophytes) damaged by invertebrate grazing in running water and, summarizing Whitehead (1935), that "remarkably few invertebrates feed directly on them." Newman (1991) presented evidence suggesting that macrophytes were important food sources for aquatic communities but concluded that most herbivory was by rare taxa that were specialized oligophagous herbivores that represented families and orders of primarily terrestrial insect groups.

In an effort to resolve this controversy, France (1995b) compiled $\delta^{13} \mathrm{C}$ results from the literature for benthic animals, macrophytes, and associated epiphytic algae from 4 different environments in North America (seagrass meadows, estuarine salt marshes, rivers, and lakes) and found little evidence for direct assimilation of macrophyte $C$ in any of these environments. Bunn et al. (1999) found that macrophytes were isotopically distinct from most consumers in Australian rivers and probably contributed little to aquatic food webs in these rivers.

\section{Cyanobacteria}

Cyanobacteria were ${ }^{13} \mathrm{C}$ enriched compared with scrapers, and scraper and cyanobacterial $\delta^{13} \mathrm{C}$ were poorly correlated. These results suggest cyanobacteria are not a $C$ source in the study rivers. Many cyanobacteria possess morphological defenses that reduce grazing pressure. Long filaments and large colonies, called flakes, can be difficult for herbivores to ingest (Lampert 1987). Freshwater cyanobacteria have toxic defense compounds (Carmichael 1981) that deter grazing by herbivorous zooplankton or reduce herbivore abundance by interfering with physiological processes (Lampert 1987), and toxic compounds produced by marine cyanobacteria deter feeding by fish and invertebrates (Nagle and Paul 1999, Thacker et al. 2001). Three of the 5 genera found in our study contain toxins that deter herbivory: Tolypothrix (Thacker et al. 2001), Lyngbya (Yin et al. 1997), and Nostoc (Carmichael 1997).

\section{Filamentous algae}

Filamentous algae also were ${ }^{13} \mathrm{C}$ enriched compared with scrapers, and scraper and algal $\delta^{13} \mathrm{C}$ were poorly correlated. These results suggest filamentous algae are not a $C$ source in the study rivers. Doucett et al. (1996) found no evidence of direct grazing of the filamentous chlorophyte, Cladophora sp., by the primary consumer, Glossosoma (Trichoptera), in another NB river system (Miramichi). Like cyanobacteria, green and red filamentous algae have physical properties that reduce herbivory. For example, gelatinous green algae pass through the guts of zooplankton unharmed because they have an indigestible sheath (Porter 1977). Bunn et al. (1999) found that filamentous algae were isotopically distinct from most consumers in Australian rivers and probably contributed little to aquatic food webs in these rivers.

\section{Bryophytes}

Mosses influence the structure of invertebrate communities by providing habitat for colonization, surfaces for the growth of epiphytic algae and accumulation of detritus, refuge from predators or high current velocities, and material for case construction (Glime and Clemons 1972, Suren 1988, Suren and Winterbourn 1992). However, few invertebrates are thought to consume aquatic bryophytes directly (Bunn et al. 1989, Glime 2006). Our results might suggest otherwise. Most fractionation values associated with trophic transfer $\left(\Delta \delta^{13} C\right)$ fell within a range of 0 to $5 \%$ enrichment. The amount of trophic fractionation can vary between individuals and consumer species, and similar ranges of $\Delta \delta^{13} \mathrm{C}$ were reported by DeNiro and Epstein (1978) and Post (2002). However, trophic fractionation is primarily an enrichment process (DeNiro and Epstein 1978) rather than a depletion process. Therefore, our $\delta^{13} \mathrm{C}$ results for mosses were significant when compared with $\delta^{13} \mathrm{C}$ the other primary producers tested.

An increasing number of studies have reported consumption of aquatic bryophytes (Hynes 1970, Gerson 1972, Winterbourn et al. 1986, Suren 1988, Suren and Winterbourn 1991, Glime 2006). For example, crustaceans, gastropods, mites, tardigrades, and many groups of insects consume bryophytes (Gerson 1972, Richardson 1981). In aquaria, lakedwelling snails consumed the aquatic moss Fissidens fontanus but not Fontinalis sp. (Lohammer 1954). Fecal analyses indicated that the aquatic isopod Asellus militaris regularly consumed Fontinalis antipyretica in the wild (Bowden et al. 1999). Suren (1988) compared invertebrate assemblages on real and artificial mosses and found significant decreases in the abundance of certain taxa on artificial mosses, a result indicating that some organisms were dependent on the bryophytes for food. Moss fragments were found in the 
guts of 14 of 23 species collected from shaded and unshaded alpine streams in New Zealand, but the frequency of occurrence was low, except for 3 species that had consumed significant amounts of the bryophytes (Suren and Winterbourn 1991).

Bryophytes can contain a number of phenolic compounds, lignin-like compounds, and terpenes that deter herbivory, particularly in leaves, that can influence the part of the plant that is consumed. Harvester ants (Messor sp.; Loria and Herrnstadt 1980), lemmings (Dicrostonyx spp.; Pakarinen and Vitt 1974), and woodland slugs (Arion spp.; Jennings and Barkham 1975) consume terrestrial moss capsules. Terrestrial isopods consumed significantly more leaves than tough stems of 2 Polytrichum species, despite their high phenolic content (Glime 2006).

Aquatic mosses often are regarded as low-quality food. However, Fontinalis antipyretica is not nutritionally inferior to other plants (Bowden et al. 1999, Glime 2006) and should be a prime food source for many aquatic organisms (Glime 1994). Winterbourn et al. (1986) found that the nutritive value of bryophyte tissues did not differ greatly from that of nearby vascular plants, and 5 species of bryophytes tested by Suren and Winterbourn (1991) had at least as much lipid, carbohydrate, and $\mathrm{N}$ content as common grass, shrub, and tree foliage, although holocellulose, crude fiber, and ash content were slightly higher. $\mathrm{N}$ content often is used as an indicator of food quality and can be assessed with C:N ratios, where a low value indicates good quality as a food source (Jardine et al. 2005). Bryophytes in our study system have lower C:N ratios $(26.5 \pm 6.0)$ than does conditioned leaf litter (32.9 \pm 14.1) from the same sites (SMM-H, unpublished data), further indicating that moss is not nutritionally inferior.

Bryophytes might be an important alternate (marginal) food source when a preferred food is unavailable. In terrestrial environments, when food sources are limited or unavailable (e.g., during winter), harvester ants feed on terrestrial moss capsules (Loria and Herrnstadt 1980), and populations of caribou (Rangifer tarandus grantii) and reindeer (Rangifer tarandus tarandus) feed on various mosses (White and Trudell 1980). In the laboratory, the detritivorous caddisfly larvae Zelandopsyche ingens consumed the aquatic moss Fontinalis rigidulus rather than less desirable terrestrial foods, such as yellow beech (Nothofagus spp.) leaves and clean twigs (Winterbourn and Davis 1976). Thus, aquatic macroinvertebrates that do not typically consume aquatic mosses might do so if preferred food sources (e.g., diatoms) are scarce. Abundances of primary producers were not measured in our study rivers, but water chemistry and nutrient data (SMM-H, unpublished data) show that these rivers have low productivity and are $\mathrm{P}$ limited. In unproductive systems, bryophytes are better able than algae to sequester nutrients (Bowden et al. 1999). Therefore, we suggest that the availability of a preferred food source might be so limited in our system that primary consumers (i.e., scrapers) use an alternate food source, aquatic bryophytes.

$\delta^{13} \mathrm{C}$ of Fontinalis sp. was more strongly correlated with scraper $\delta^{13} \mathrm{C}$ than was $\delta^{13} \mathrm{C}$ of Drepanocladus sp. Fontinalis spp. are always found submerged (Grout 1903) and cannot survive even a week of air-drying (Watson 1964), whereas Drepanocladus species are not as sensitive to desiccation and can be found at the edges of brooks and growing on emergent rocks in splash zones (Grout 1903). In our system, Fontinalis $\mathrm{sp}$. was more abundant in low-order reaches, where it grew large strands $(\geq 50 \mathrm{~cm})$ and frequently colonized $>75 \%$ of the substrate surface. Drepanocladus sp. was more abundant in higher-order reaches and grew in shorter tuffs $(\sim 5 \mathrm{~cm})$. Bryophyte abundance was substantially lower in high- $(\sim 5 \%$ of substrate surface) than in low-order reaches. Thus, ecological differences might have limited the availability of Drepanocladus sp. to scrapers and reduced its importance to local food webs relative to Fontinalis sp.

Our results suggest that aquatic mosses might be a primary $C$ source for grazing aquatic invertebrates in the BSR and USR. The possibility that a potential macroscopic autochthonous food source was not sampled is unlikely given the spatial and temporal extent of sampling. However, microscopic food sources, such as epiphytes or bacteria growing on the bryophytes, might have $\delta^{13} \mathrm{C}$ signatures similar to those of bryophytes, and could provide an alternate explanation for the correspondence between scraper and bryophyte isotope ratios observed. Large amounts of periphyton (Johnson 1978, Suren 1988) and detritus (Johnson 1978) commonly are associated with bryophytes. Dissolved organic matter and plant nutrients released from moss cells (Wetzel 1983) might enhance the growth of the surrounding periphyton. Bryophytes use only dissolved $\mathrm{CO}_{2}$ for photosynthesis, whereas algae can use $\mathrm{HCO}_{3}{ }^{-}$when $\mathrm{CO}_{2}$ is scarce (Bowden et al. 1999, Finlay 2004). However, algae use dissolved $\mathrm{CO}_{2}$ preferentially, and $\mathrm{CO}_{2}$ should be available in high concentrations in low-productivity systems. Thus, epiphytes could have $\delta^{13} \mathrm{C}$ values similar to those of bryophytes in our system (Finlay 2004). Bacterial $C$ is derived from dissolved organic $C$ and particulate detritus and should have a $\delta^{13} \mathrm{C}$ signature that reflects these sources (Hall 1995). Therefore, bacteria growing on the surface of bryophytes could have $\delta^{13} \mathrm{C}$ values similar to those of the bryophytes. 
Hall (1995) found that bacterial C was an important C source to the food web in a headwater stream and that the scraper Stenonema (Heptageniidae) fed predominantly on bacterial C. Thus, we are unable to completely exclude epiphytes and bacteria as possible food sources.

FFGs other than scrapers also can rely on autochthonous food sources to varying degrees. Collectorgatherers consume particulate organic matter, which is typically a combination of autochthonous and allochthonous $C$ sources and their associated microbes, from the sediment (Vannote et al. 1980). In our study, allochthonous $\mathrm{C}$ remained relatively unchanged (SMM$\mathrm{H}$, unpublished data). Therefore, spatial and temporal changes in collector-gatherer $\delta^{13} \mathrm{C}$ should reflect changes in autochthonous C (Bunn et al. 2003). Similarly, collector-gatherer $\delta^{13} \mathrm{C}$ was poorly correlated with macrophyte $\left(r=0.29, r^{2}=0.08,80 \%\right.$ of values below the 1:1 line), cyanobacteria $\left(r=0.55, r^{2}=0.30,88 \%\right.$ below 1:1), filamentous algae $\left(r=0.47, r^{2}=0.22,54 \%\right.$ below 1:1), and biofilm $\left(r=0.51, r^{2}=0.26,52 \%\right.$ below 1:1) $\delta^{13} \mathrm{C}$. However, bryophyte $\delta^{13} \mathrm{C}$ was well correlated with collector-gatherer $\delta^{13} \mathrm{C}\left(r=0.76, r^{2}=0.58\right)$, and $97 \%$ of values were above the 1:1 line, indicating that collector-gatherer $\delta^{13} \mathrm{C}$ was enriched relative to bryophyte $\delta^{13} \mathrm{C}$. Collector-gatherers might have consumed all vegetation types, but the strong correlation with bryophytes strengthens the idea that aquatic mosses are supporting the autochthonous portion of food webs in these unproductive river systems.

In conclusion, many potential aquatic food sources can contribute to food webs throughout a river system. Our results indicate that macrophytes, filamentous algae, and cyanobacteria were not important food sources to invertebrates in the USR and BSR. Biofilm also seemed unimportant in local food webs but could not be excluded as a potential food source. Scrapers appeared to use aquatic bryophytes as their primary autochthonous food source, although the possibility that grazers were consuming isotopically similar epiphytes and bacteria growing on bryophyte surfaces could not be eliminated. However, this possibility does not exclude use of moss $\delta^{13} \mathrm{C}$ as an autochthonous $C$ source in subsequent mixing models for the USR and BSR rivers. The low productivity and nutrient-limited nature of these river systems might severely reduce the availability of preferred food sources and require that primary consumers switch to an alternate food source. Confirming that aquatic bryophytes are this alternate food source will require additional studies, such as tracer additions or gut content analysis. However, our results suggest that aquatic mosses are important food sources in low-productivity streams.

\section{Acknowledgements}

Funding and in-kind support for this study were provided by Fundy National Park (Parks Canada) through the helpful involvement of Renee Wissink. The Canada Research Chairs grant awarded to RAC and the Atlantic Salmon Federation's Olin Fellowship and University of New Brunswick's Vaughan Graduate Fellowship to SMM-H provided additional funding. The authors thank Rachel Keeler, Peter Batt, Alex Ready, and Aaron Fraser for all their assistance. We also thank Gary Saunders (University of New Brunswick), who helped identify the filamentous algae samples. Comments provided by 2 anonymous referees greatly improved this manuscript.

\section{Literature Cited}

Allan, J. D. 1995. Stream ecology: structure and function of running waters. Chapman and Hall, New York.

Biggs, B. J. F. 1996. Patterns in benthic algae of streams. Pages 31-56 in R. J. Stevenson, M. L. Bothwell, and R. L. Lowe (editors). Algal ecology: freshwater benthic ecosystems. Academic Press, San Diego, California.

Bowden, W. B., D. Arscott, D. Pappathansi, J. Finlay, J. M. Glime, J. Lacroix, C.-L. Liao, A. Hershey, T. Lampella, B. Peterson, W. Wollheim, K. Slavik, B. Shelley, M. B. Chesterton, J. A. Lachance, R. M. Leblanc, A. Steinman, AND A. Suren. 1999. Roles of bryophytes in stream ecosystems. Journal of the North American Benthological Society 18:151-184.

Bunn, S. E., D. R. Barton, H. B. N. Hynes, G. Power, And M. A. Pope. 1989. Stable isotope analysis of carbon flow in a tundra river system. Canadian Journal of Fisheries and Aquatic Sciences 46:1769-1775.

Bunn, S. E., P. M. Davies, And T. D. Mosisch. 1999. Ecosystem measures of river health and their response to riparian and catchment degradation. Freshwater Biology 41: 333-345.

Bunn, S. E., P. M. DAvies, And M. Winning. 2003. Sources of organic carbon supporting the food web of an arid zone floodplain river. Freshwater Biology 48:619-635.

BunN, S. E., N. R. Loneragan, AND M. A. Kempster. 1995. Effects of acid washing on stable isotope ratios of $\mathrm{C}$ and $\mathrm{N}$ in penaeid shrimp and seagrass: implications for food-web studies using multiple stable isotopes. Limnology and Oceanography 40:622-625.

CARmichael, W. M. 1981. Freshwater blue-green algae (Cyanophyta) toxins-a review. Pages 1-13 in W. M. Carmichael (editor). The water environment. Plenum, New York.

Carmichael, W. W. 1997. The cyanotoxins. Advances in Botanical Research 27:211-256.

Chapman, D. W. 1966. The relative contribution of aquatic and terrestrial primary producers to the trophic relations of stream organisms. Special Publication of the Pymatuning Laboratory of Field Biology 4:116-130. 
CRAIG, H. 1957. Isotopic standards for carbon and oxygen and correction factors for mass spectrometric analysis of carbon dioxide. Geochimica et Cosmochimica Acta 12: 133-263.

Cummins, K. W. 1974. Structure and function of stream ecosystems. BioScience 24:631-641.

Cummins, K. W. 1975. Macrophytes. Pages 170-198 in B. A. Whitton (editor). River ecology. Blackwell, Oxford, UK.

CUnJAK, R. A., AND R. W. Newbury. 2005. Atlantic coast rivers of Canada. Pages 939-980 in A. C. Benke and C. E. Cushing (editors). Rivers of North America. Elsevier (Academic Press), San Diego, California.

Deniro, M. J., AND S. EPSTEIN. 1978. Influence of the diet on the distribution of carbon isotopes in animals. Geochimica et Cosmochimica Acta 42:495-506.

Deniro, M. J., AND S. EPSTEIN. 1981. Influence of the diet on the distribution of nitrogen isotopes in animals. Geochimica et Cosmochimica Acta 45:341-351.

Doucett, R. R., G. Power, D. R. Barton, R. J. Drimmie, and R. A. Cunjak. 1996. Stable isotope analysis of nutrient pathways leading to Atlantic salmon. Canadian Journal of Fisheries and Aquatic Sciences 53:2058-2066.

Environment Canada. 2007. Environment Canada Water Survey. Environment Canada, Gatineau, Quebec. (Available from: http:/ / www.wsc.ec.gc.ca/hydat/H2O/ index_e.cfm)

FINLAY, J. C. 2001. Stable-carbon-isotope ratios of river biota: implications for energy flow in lotic food webs. Ecology 82:1052-1064.

FinLAY, J. C. 2004. Patterns and controls of lotic algal stable carbon isotope ratios. Limnology and Oceanography 49: 850-861.

FrANCE, R. L. 1995a. Critical examination of stable isotope analysis as a means for tracing carbon pathways in stream ecosystems. Canadian Journal of Fisheries and Aquatic Sciences 52:651-656.

FrANCE, R. L. 1995b. Stable isotopic survey of the role of macrophytes in the carbon flow of aquatic foodwebs. Vegetatio 124:67-72.

Frohne, W. C. 1956. The provendering role of the larger aquatic plants. Ecology 37:387-388.

FRY, B. 2006. Stable isotope ecology. Springer, New York.

FrY, B., AND E. B. SHERR. 1984. $\delta^{13} \mathrm{C}$ measurements as indicators of carbon flow in marine and freshwater ecosystems. Contributions in Marine Science 27:13-47.

Gerson, U. 1972. Bryophytes and invertebrates. Pages 291-332 in A. J. E. Smith (editor). Bryophyte ecology. Chapman and Hall, London, UK.

GLime, J. M. 1994. Bryophytes as homes for stream insects. Hikobia 11:483-497.

GLime, J. M. 2006. Bryophytes and herbivory. Cryptogamie Bryologie 27:191-203.

Glime, J. M., And R. M. Clemons. 1972. Species diversity of stream insects on Fontinalis spp. compared to diversity on artificial substrates. Ecology 53:458-464.

Grout, A. J. 1903. Mosses with hand-lens and microscope. Privately published, New York.

HaLl, R. O. 1995. Use of a stable carbon isotope addition to trace bacterial carbon through a stream food web.
Journal of North American Benthological Society 14: 269-277.

Hamilton, S. K., S. J. Sippel, and S. E. Bunn. 2005. Separation of algae from detritus for stable isotope or ecological stoichiometry studies using density fractionation in colloidal silica. Limnology and Oceanography: Methods 3:149-157.

HynEs, H. B. N. 1970. The ecology of running waters. University of Toronto Press, Toronto, Ontario.

JARDINE, T. D., AND R. A. CUNJAK. 2005. Analytical error in stable isotope ecology. Oecologia (Berlin) 144:528-533.

Jardine, T. D., R. A. Curry, K. S. Heard, and R. A. Cunjak. 2005. High fidelity: isotopic relationship between stream invertebrates and their gut contents. Journal of the North American Benthological Society 24:290-299.

Jennings, T. J., AND J. P. BARKham. 1975. Food of slugs in mixed deciduous woodland. Oikos 26:211-221.

JoHnson, T. 1978. Aquatic mosses and stream metabolism in a North Swedish river. Verhandlungen der Internationalen Vereinigung für theoretische und angewandte Limnologie 20:1471-1477.

LAMPERT, W. 1987. Laboratory studies on zooplanktoncyanobacteria interactions. New Zealand Journal of Marine and Freshwater Research 21:483-490.

LoDGE, D. M. 1991. Herbivory on freshwater macrophytes. Aquatic Botany 41:195-224.

Logan, J. M., T. D. Jardine, T. J. Miller, S. E. Bunn, R. A. Cunjak, And M. E. Lutcavage. 2008. Lipid corrections in carbon and nitrogen stable isotope analyses: comparison of chemical extraction and modeling methods. Journal of Animal Ecology 77:838-846.

Lohammer, G. 1954. The distribution and ecology of Fissidens julianus in northern Europe. Svensk botanisk tidskrift 58:162-173.

Loria, M., AND I. HerRnstadt. 1980. Moss capsules as food of the harvester ant Messor. Bryologist 83:524-525.

Madsen, B. L. 1972. Detritus on stones in streams. Memorie dell' Istituto Italiano di Idrobiologia 29:385-403.

Madsen, T. V., And K. SAnd-Jensen. 1991. Photosynthetic carbon assimilation in aquatic macrophytes. Aquatic Botany 41:5-40.

McCutchan, J. H., W. M. Lewis, JR., C. Kendall, and C. C. McGrath. 2003. Variation in trophic shift for stable isotope ratios of carbon, nitrogen, and sulfur. Oikos 102: 378-390.

Merritt, K. W., and K. W. Cummins (editors). 1984. An introduction to the aquatic insects of North America. $2^{\text {nd }}$ edition. Kendall/Hunt, Dubuque, Iowa.

Nagle, D. G., AND V. J. Paul. 1999. Production of secondary metabolites by filamentous tropical marine cyanobacteria: ecological functions of the compounds. Journal of Phycology 35:1412-1421.

Newman, R. M. 1991. Herbivory and detritivory on freshwater macrophytes by invertebrates: a review. Journal of the North American Benthological Society 10:89-114.

NGS (National Geodetic Survey). 1983. North American Datum. National Geodetic Survey, National Atmospher- 
ic and Oceanographic Administration, Washington, DC. (Available from: http://www.ngs.noaa.gov/)

Odum, E. P. 1971. Fundamentals of ecology. Saunders, Philadelphia, Pennsylvania.

PAKARINEN, P., AND D. H. VitT. 1974. The major organic components and calorific contents of high arctic bryophytes. Canadian Journal of Botany 52:1151-1161.

Petelle, M., B. Haines, And E. Haines. 1979. Insect food preferences analyzed using $13 \mathrm{C} / 12 \mathrm{C}$ ratios. Oecologia (Berlin) 38:159-166.

Peterson, B. J., And B. Fry. 1987. Stable isotopes in ecosystem studies. Annual Review of Ecology and Systematics 18: 293-320.

PhILliPs, D. L. 2001. Mixing models in analyses of diet using multiple stable isotopes: a critique. Oecologia (Berlin) 127:166-170.

Porter, K. G. 1977. The plant-animal interface in freshwater ecosystems. American Scientist 65:159-170.

Post, D. M. 2002. Using stable isotopes to estimate trophic position: models, methods, and assumptions. Ecology 83:703-718.

Prescott, G. W. 1980. How to know the aquatic plants. $2^{\text {nd }}$ edition. Wm. C. Brown, Dubuque, Iowa.

RAU, G. H. 1980. Carbon-13/Carbon-12 variation in subalpine lakes aquatic insects: food source implications. Canadian Journal of Fisheries and Aquatic Sciences 37: 742-746.

Richardson, D. H. S. 1981. The biology of mosses. John Wiley and Sons, New York.

Rounick, J. S., AND M. J. Winterbourne. 1986. Stable carbon isotopes and carbon flow in ecosystems. BioScience 36: 171-177.

Rounick, J. S., M. J. Winterbourn, And G. L. Lyon. 1982. Differential utilization of allochthonous and autochthonous inputs by aquatic invertebrates in some New Zealand stream: a stable carbon isotope study. Oikos 39: 191-198.

Rowe, J. S. 1972. Forest regions of Canada. Publication 1300. Canadian Forest Service, Environment Canada, Ottawa, Ontario.

SEARS, J. R. 1998. NEAS keys to benthic marine algae of the Northeastern coast of North America from Long Island Sound to the Strait of Belle Isle. University of Massachusetts, Dartmouth, Massachusetts.

SHElford, V. E. 1918. Conditions of existence. Pages 21-60 in H. B. Ward and G. C. Whipple (editors). Freshwater biology. John Wiley and Sons, New York.

Suren, A. M. 1988. The ecological role of bryophytes in high alpine streams of New Zealand. Verhandlungen der Internationalen Vereinigung für theoretische und angewandte Limnologie 23:1412-1416.

Suren, A. M., And M. J. Winterbourn. 1991. Consumption of aquatic bryophytes by alpine stream invertebrates in New Zealand. New Zealand Journal of Marine and Freshwater Research 25:331-343.
Suren, A. M., And M. J. Winterbourn. 1992. The influence of periphyton, detritus and shelter on invertebrates colonization of aquatic bryophytes. Freshwater Biology 27: 327-339.

Thacker, R. W., D. W. Ginsburg, and V. J. Paul. 2001. Effects of herbivore exclusion and nutrient enrichment on coral reef macroalgae and cyanobacteria. Coral Reefs 19: 318-329.

Thorp, J. H., M. D. Delong, K. S. Greenwood, and A. F. CASPER. 1998. Isotopic analysis of three food web theories in constricted and floodplain regions of a large river. Oecologia (Berlin) 117:551-563.

VANDER ZANDEN, M. J., AND J. B. RASMUSSEN. 2001. Variation in $\delta^{15} \mathrm{~N}$ and $\delta^{13} \mathrm{C}$ trophic fractionation: implications for aquatic food web studies. Limnology and Oceanography 46:2061-2066.

Vannote, R. L., G. W. Minshall, K. W. Cummins, J. R. Sedell, AND C. E. Cushing. 1980. The river continuum concept. Canadian Journal of Fisheries and Aquatic Sciences 37: 130-137.

WAtson, E. V. 1964. The structure and life of bryophytes. Hutchinson and Co. London, UK.

Wetzel, R. G. 1975. Limnology. W. B. Saunders, Philadelphia, Pennsylvania.

Wetzel, R. G. 1983. Attached algae-substrata interactions: fact or myth, and when and how? Developments in Hydrobiology 17:207-217.

White, R. G., AND J. Trudell. 1980. Habitat preference and forage consumption by reindeer and caribou near Atkasook, Alaska. Arctic and Alpine Research 12: 511-529.

WhiteHEAd, H. 1935. An ecological study of the invertebrate fauna of a chalk stream near Great Driffield, Yorkshire. Journal of Animal Ecology 4:58-78.

Winterbourn, M. J., AND S. F. DAvis. 1976. Ecological role of Zelandopsyche ingens (Trichoptera: Oeconesidae) in a beech forest stream ecosystem. Australian Journal of Marine and Freshwater Research 27:197-215.

Winterbourn, M. J., J. S. RounicK, AND A. G. Hildrew. 1986. Patterns of carbon resource utilization by benthic invertebrates in two British river systems: a stable isotope study. Archiv für Hydrobiologie 107:349-361.

Woodley, S. J. 1985. Fundy National Park, resource description and analysis. Resource Conservation Section, Fundy National Park, Alma, New Brunswick. (Available from: Resource Conservation Section, Fundy National Park, Alma, New Brunswick, Canada E4H 1B4.)

Yin, Q., W. W. Carmichael, and W. R. Evans. 1997. Factors influencing growth and toxin production by cultures of freshwater cyanobacterium Lyngbya wollei Farlow ex Gomont. Journal of Applied Phycology 9:55-63.

Received: 24 July 2008 Accepted: 4 June 2009 